the deficiency is 24. After these, the next most serious shortages are in English and foreign languages. In comprehensive schools, which as a whole aro of more rocent construction, the shortages are still greater, the figures boing 68 for mathematics, and 59 for science--along with 32 for English, 27 for geography, 23 for foreign languages and 22 for history. Once again this survey brings out the meagre provision in both typos of sehool for the teaching of engineering, mechanical and geometrical drawing, and rural science. Most of the larger grammar schools and three-quarters of the smaller ones obtain some assistance with laboratory work. Among other deficiencies of various kinds which the survey reveals, one striking fact is the acute shortage in comprehensive schools of teachers specially trained to teach backward children. These deficiencies are not merely matters of school administra. tion, for it is clear that, to a certain extent, among young people, a scientific attitude can be fostered by appropriate upbringing and training; while in varying degree there is scope for scientific ability at all levels and in all sectors of society. The deficiencies, therefore, are symptomatic of weaknesses in Britain's national culture.

\section{Research in South African National Parks}

The varied subjects of the papers published in Koedoe, the journal for seientific research in the national parks of the Republic of South Africa (No. 6; 1963), show the seale of the work being carried out under the auspices of the National Parks Board of Trustees. A number of systematic and distributional investigations of both vertebrates and invertebrates is included as well as several very interesting contributions on the use of different immobilizing drugs in the capture of large mammals. The tuse of such drugs is rapidly becoming widespread not only for bringing wild animals into captivity, but also in the scientific study of their biology, for it enables close examination to be made and marking by ear-tags or other means to be carried out. An interesting collection of photographs illustrates the technique by which a syringe containing the drug is incorporated in a dart fired from a special gun or crossbow. A drug for use with all species of mammals has not yet been made, but excellent results are being obtained by combining the immobilizing and tranquillizing drugs in varying doses according to species. A paper by Pionaar and Van Niekerk describes the use of a tranquillizer on a number of oribi captured by driving them into nets in order to introduce them into the Kruger National Park, where the species became extinct in 1943 .

\section{The National Art Gallery and Dominion Museum, New Zealand}

As with so many museums and art galleries, both in Britain and abroad, the real bottleneck at the National Art Gallery and Dominion Museum, New Zealand, is not finance but space for exhibits, for storage and for working. While plans under consideration for the transfer of the Art Gallery to a new building may provide an ultimate solution, the Museum must seek some immediate relief within a much shorter time than it will take to build a new Art Gallery. The annual report for the year ended March 31, 1963, states that efforts have boen made to persuade the Police Department to vacate the building on the Board's property which is still used as a clothing store (Pp. 26. Wellington, New Zealand: Government Printor, 1963. 1s.6d.). Public relations are given constant attention, and in recognition of a considerable degree of municipal support the Museum tries to make its contribution as a civic community.

The Yale Peabody Museum of Natural History, New Haven, Connecticut

AnNUat Report No. 4-1963 of the Yale Peabody Museum of Natural History, New Haven, Connecticut, is the record of a progressive institution with a relatively large staff engaged on research and teaching as well as normal museum activities (Pp. $60+13$ photographs. New Haven, Conn.: Yale Peabody Museum of Natural History, 1963). Dr. S. Dillon Ripley, the director, stresses the fact that research leads to the development and refinement of the exhibits. Sarawak Museum in Borneo presented four specimens of Lanthanotus borneensis, one of the rarest and most primitive of living reptiles. It is an earless animal, of which only eighteon specimens are known in the world, and figures significantly in the hypothesis that snakes were derived from some monitor-like lizard in that it possesses many of the structures to be expocted in an ancestor. It was discovered in 1878, and so little is known of its habits that the first observation of its feeding occurred in New Haven in 1963.

\section{The Smithsonian Institution, Washington}

THE annual report of the Smithsonian Institution for 1962 is, as usual, a large volumo of several hundred pagos recording the strengthening of the academic staff, and progress in the renovation of the exhibits (Pp. $\mathrm{x}+610+$ 106 plates. Washington, D.C.: Government Printing Office, 1963. 4.75 dollars). Attendances reached the high figure of $8,923,131$-an indication of the popularity of the Smithsonian Institution. The great study collections are utilized by hundreds of research workors from other Government bureaux and from universities all over the United States. The total numbor of catalogued objects now in the Smithsonian is nearly 56 million. When the east and west wings of the Natural History Building are completed and opened for use and when the great new Museum of History and Technology is open, the effectiveness of the whole pattern of public display and of the use of study collections will be greatly appreciated.

\section{Register of Research in the Human Sciences (1960-63)}

THE second edition of the Register of Research in the Human Sciences (1960-63), compiled by the Warren Spring Laboratory of the Department of Scientific and Industrial Research, has recently been published (Pp. vi+226. London: H.M.S.O., 1963. 20s. net). The new edition presents a much more comprehensive account of research in this field and in fact contains twice as many entries as its predecessor. Included within this title of "Human Sciences" are abnormal psychology, demography, developmental psychology, experimental psychology, industrial psychology, industrial sociology, physiological psychology, public administration, rural sociology, social anthropology, social disorganization, social economies, social geography, social history, social medicine, social psychology, social stratification, and urban sociology. The entries are arranged in broad subject headings and underneath are grouped in alphabetical order the names of the research institutions. Throughout, the rosearch projects are numbered. Then follows a brief description of tho projects, the person (or committee) responsible for the research, research workers, approximate starting date, approximate date of completion, interim results, final results, parties concerned with enquiries and other information. Two indexes are provided; the first deals with institutions giving address, telephone number, name of person in charge, etc.; the second is a subject index covering all fields from "absenteeism" through "crime", "housing", "management", "rural communities", "smoking", "undor-developed countries", to "youth groups", etc.

\section{Family Planning}

FACED with a world population which could possibly be double that of the present $3,000,000,000$ within forty years, the Family Planning Association has decided to launch a massive internstional campaign. The fact that 